\title{
poder municipal e as concessões de serviços públicos no brasil no início do século $\mathrm{xx}$
}

\author{
Cláudia Regina Salgado de Oliveira Hansen* \\ Mestre em História - UFF \\ Alexandre Macchione Saes** \\ Doutorando em História Econômica - UNICAMP e bolsista da FAPESP
}

RE S U M O

\begin{abstract}
A proposta do artigo é mapear a evolução política e econômica da Companhia Brasileira de Energia Elétrica (CBEE) nos Estados de São Paulo e do Rio de Janeiro, identificando os entraves e os êxitos da empresa na aquisição de concessões municipais. Avaliando as relações políticas no âmbito municipal, é possível compreender os arranjos políticos e os principais grupos de interesse existentes no período. Por mais respeitáveis que fossem as decisões estaduais e federais, não existia um projeto nacional sobre as concessões dos serviços públicos naquele momento. Logo, as decisões sobre os serviços de eletricidade estavam à mercê dos arranjos políticos na Câmara Mu nicipal e das relações entre empresários e vereadores.

Palavras-Chave: Concessão de serviços públicos, CBEE e Poder Municipal
\end{abstract}

\begin{abstract}
A B S T R AC T
The proposal of this paper is to chart the political and economic path of the Companhia Brasileira de Energia Elétrica (CBEE) in the states of São Paulo and Rio de Janeiro. It identifies the enterprise's obstacles and suecesses in bidding for $\mathrm{mu}$ nicipal concessions. By evaluating the political relations in the municipal scope, it is possible to understand the political arrange,ment and the most important political groups in the period. Even though the Federal and State decisions were binding for the entire country, there was not a national project regarding public Utilities concession. Thus, decisions in Brazil's electric power sector depended on the economic power and political lobby of entreprenetirs and town councilors.
\end{abstract}

Keywords: Public utilities concession, CBEE and Municipal Power

A formação das empresas de serviços públicos no Brasil pode ser datada do período de segunda metade do século XIX. Entretanto, foi somente no início do século XX que tais empresas tomaram maior vigor e passaram a colaborar de maneira determinante nas transforma-

\footnotetext{
* e-mail: claudia_hansen@uol.com.br

**e-mail: xixosaes@hotniail.com. Submetido:janeiro,2006; aceito: outubro, 2006.
} 
ções da sociedade brasileira. Entre os serviços públicos, destacaram-se a produção e a distribuição de energia elétrica, ora para a iluminação e o transporte público, ora para a iluminação particular e o fornecimento de energia para indústrias e serviços fundamentais para impulsionar os processos de urbanização e industrialização.

O setor de serviços público e urbano no Brasil, na passagem para o século XX, tornou-se uma forma de investimento extremamente rentável, atraindo capitais estrangeiros que tão logo passavam a dominar os principais mercados brasileiros. Este foi o caso das empresas de energia elétrica, como a canadense Light, na cidade de São Paulo em 1899, e no Distrito Federal em 1905, e da americana American Foreign Power Co. (AMFORP), grupo ligado a Bond \& Share, que, na década de 1920, começou a controlar diversas capitais nordestinas, além de cidades importantes no interior de São Paulo e do Rio de Janeiro. Contudo, mesmo que a presença estrangeira fosse notável, grupos nacionais buscaram difundir-se e estabelecer companhias de fornecimento de energia elétrica nos mercados emergentes. Neste sentido, a Companhia Brasileira de Energia Elétrica (CBEE), empresa vinculada ao grupo dos empresários Eduardo P. Guinle e Cândido Gaffrée, a Guinle \& Co., foi a principal empresa brasileira a concorrer com o capital estrangeiro, em especial contra a Light, nas duas primeiras décadas do século XX.

A associação dos Guinle com Cândido Gaffrée deu origem à construção de um grupo empresarial de peso a partir da segunda metade do século XIX. Este império empresarial não se fez à revelia do Estado, nem em seu sentido estrito, nem em seu sentido amplo'. Com a concessão das obras do Porto de Santos, tarefa desempenhada pela empresa Docas de Santos, a "família Guinle" passou a estender os seus tentáculos a vários outros setores, inclusive ao de serviços públicos de energia elétrica (HONORATO, 1996:15). Estes serviços, no Distrito Federal e em São Paulo - os dois mais promissores mercados consumidores de energia elétrica do país - levaram o grupo a disputar espaços com a empresa canadense Light $^{2}$.

\footnotetext{
Entendemos o Estado como uma relação social, ou seja, um espaço onde se condensam as relações interpessoais de uma dada sociedade; um espaço de consenso, obtido através dos aparelhos privados de hegemonia (sociedade civil) e do Estado restrito (sociedade política), além das relações entre tais elementos (GRAMSCI, 1978).

${ }^{2}$ Foi bastante grande também a disputa entre estes grupos na Bahia. No entanto, esta não será aqui abordada.
} 
No entanto, apesar de sabermos que a Light era uma poderosa empresa de capital estrangeiro e com grande capacidade de investimento no setor elétrico, não acreditamos que este aspecto tenha sido o único determinante para sua vitória como empresa prestadora de serviços públicos de eletricidade, tanto no Distrito Federal quanto na cidade de São Paulo. Ao observarmos mais de perto os embates entre estas duas empresas, percebemos que as relações políticas, associadas aos aspectos institucionais, tiveram também um papel importante em todo o processo de disputas e, é claro, em seus resultados.

O que pretendemos é mostrar algumas das relações políticas do "grupo Guinle \& Co.", em São Paulo e no Distrito Federal, ou seja, algumas das relações do grupo com diversas personae políticas importantes que ocuparam cargos públicos na Primeira República e que também estavam presentes em entidades de representação dos empresários, na tentativa de associar suas ligações e articulações políticas a estas pessoas, com o ganho de determinadas concessões ou contratos para executarem serviços públicos de eletricidade, ou mesmo vantagens em alguns momentos da disputa CBEE/Light.

Logo, o objetivo do artigo é reconstruir a trajetória política da Companhia Brasileira de Energia Elétrica nos Estados do Rio de Janeiro e de São Paulo, identificando os entraves e os êxitos da empresa na aquisição de concessões municipais. Avaliar as relações políticas no âmbito municipal torna-se central, pois, por mais respeitáveis que fossem as decisões estaduais e federais, não existia, no período, um projeto nacional sobre as concessões dos serviços públicos. Logo, as decisões sobreos serviços de eletricidade estavam à mercê dos arranjos políticos na Câmara Municipal e das relações entre empresários e vereadores, por mais que tanto a Light como a CBEE também abusassem das relações cordiais com todas as formas de poder.

\section{Articulações políticas dos Guinle em fins do século $X I X$ e início do século $X X$}

Jorge Street, Gabriel Osório de Almeida, Saturnino Cândido Gomes, Eduardo Palassin Guinle, Eduardo Guinle, Guilherme Guinle e Cândido Gatfrée eram alguns dos nomes importantes da CBEE.Todos estiveram presentes em entidades de representação de classe dos 
empresários ou em órgãos públicos, no momento em que a CBEE, sucessora da Guinle \& Cia.,buscava consolidar-se como uma grande empresa de serviços públicos no Brasil. Além de acionistas da CBEE, os empresários eram sócios do Clube de Engenharia, fundado em 24 de dezembro de 1880 , na cidade do Rio de Janeiro, institucionalizando as reuniões de engenheiros que se realizavam nas dependências da papelaria de propriedade de Conrado Niemeyer, à Rua da Alfândega, ${ }^{\circ} 6$, destinando o sobrado da loja à instalação da primeira sede do Clube, que virou uma instituição a serviço da engenharia, promovendo conferências, exposições e congressos, elaborando pareceres sobre inúmeras consultas formuladas pelo governo, por empresas e particulares, e publicando, além da sua revista, diversos documentos e memórias, estabelecendo, inclusive, ligações com industriais da época. Os próprios estatutos realçavam que entre seus objetivos estavam estruturadas relações entre as classes de engenheiros e os vários ramos de industriais ${ }^{3}$.

Art. $1^{\circ}$ - A sociedade - Clube de Engenharia tem por objeto promover e estreitar relações entre as classes de engenharia e as dos vários ramos industriais, no que diz respeito aos interesses recíprocos das suas funções.

Art. $4^{\circ}\left(\S 2^{\circ}\right)$. Reunir todos os dados e elementos concernentes ao comércio, indústria e artes para formular mensal e anualmente suas tabelas ${ }^{4}$.

Em 1874, com a criação da Escola Politécnica do Rio de Janeiro, em substituição à Escola Central, a formação do engenheiro civil ganhou plena autonomia, desvinculando-se do ensino militar. A escola se manteve como o principal centro gerador da engenharia nacional e o Clube de Engenharia, criado em 1880, surgia como uma extensão quase natural da Escola Politécnica, pois congregava quase todos os recém-formados alunos da escola. Além de engenheiros, o Clube reuniu também negociantes e políticos de várias partes do país, sobretudo do Rio de

\footnotetext{
Sobre as relações possíveis de se estabelecerem entre os engenheiros e a indústria, conferir os trabalhos de KAWAMURA (1981) e TURAZZI (1989).

4 Estatutos do Clube de Engenharia, aprovados pelo Decreto ${ }^{\circ}$ 8.253, de 10 de setembro de 1881. Rio de Janeiro: Tipografia Nacional, 1881.
} 
Janeiros. Estes homens, em sua maioria, estavam contagiados pelas idéias de progresso, civilização e ordem ${ }^{6}$.

A participação dos Guinle e dos homens a eles ligados neste Clube foi bastante significativa. Eduardo P. Guinle, filiado em 1885, foi o $2^{\circ}$ Vice-Presidente do Clube de Engenharia, de 1900 a 1912; quando faleceu, foi substituído por ninguém menos que seu grande parceiro Cândido Gaffrée, filiado em 1882. Este, enquanto Eduardo P. Guinle eraVice-Presidente, fazia parte do Conselho Fiscal da instituição.Jorge Street, filiado em 1896, vai suceder a Cândido Gaffrée. Gabriel Osório de Almeida, filiado em 1891, vai ser Presidente do Clube de 1900 a 1902, tornando-se um dos membros do Conselho Diretor e, mais tarde, membro vitalício do Clube. Em 1913, Guilherme Guinle, filho de Eduardo Guinle, entrava para o Conselho Diretor ${ }^{7}$.

Partindo do pressuposto de que o Estado não é tão somente o conjunto de aparelhos e agências do poder público propriamente dito, mas também o conjunto dos indivíduos organizados nos chamados aparelhos privados de hegemonia (GRAMSCI, 1966), e de que o Clube de Engenharia correspondia a um destes aparelhos, ou seja, a um espaço de ação política consciente, pretendendo alcançar certos objetivos, verificamos que aí, de alguma forma, o grupo de empresários ligados aos Guinle - e eles próprios - criavam ligações políticas importantes para a expansão dos seus negócios de eletricidade ${ }^{8}$. O Clube de Engenharia era um espaço de debates importantes,

[...] que alcançou uma posição de destaque na sociedade brasileira, elaborando pareceres e consultas técnicas, promovendo congressos e exposi-

${ }^{5}$ Os 9 presidentes do Clube de Engenharia, no período de 1880 a 1930, foram formados, em sua maioria, na Escola Militar do Rio de Janeiro, Escola Central e Escola Politécnica do Rio de Janeiro. Eram oriundos do Estado do Rio de Janeiro (6) e Minas Gerais (3). Revista do Clube de Engenharia, 1922:49-57.

Grande parte das pessoas do patronato, ligadas às associações de classe, estudou na Escola Militar e Central, depois transformada em Escola Politécnica do Rio de Janeiro, na Faculdade de Medicina do Rio, no Colégio D. Pedro 11 e no Liceu de Artes e Ofícios, onde havia muitos adeptos de doutrinas como o evolucionismo, o positivismo, o naturalismo e o darwinismo social, "enfim, todo um cientificismo que tomou conta do pais na segunda metade do século XIX" ( T URAZZI, 1989: 38-39).

Biblioteca Do Clube De Engenharia. Revista do Clube de Engenharia. $N^{\circ} 1-26(1900-1913$ e 1922).

Claro que esta associação é aqui considerada como um aparelho privado de hegemonia, um espaço onde há organização de interesses de determinadas frações 
ções, ou ainda, influenciando a concepção urbanística do país. Essa posição era reforçada, sobretudo, pela proeminência política e social de muitos de seus membros e pela formação e competência técnica dos sócios engenheiros, pela experiência e pelos recursos dos sócios industriais e negociantes ( T URAZZI, 1989:42).

E o resgate da trajetória do engenheiro Gabriel Osório de Almeida, presidente do Clube de Engenharia, cujos pareceres do Conselho Diretor eram muito importantes para decisões do governo", e um dos homens fortes do Grupo Guinle ${ }^{10}$, pode contribuir para perceber as relações que os Guinle vão conseguir estabelecer no Distrito Federal.

Gabriel Osório, nascido na cidade de Pouso Alegre (MG), em 1854, e matriculado em 1874 na Escola Central, formou-se engenheiro em 24 de dezembro de 1880. Começou sua carreira ferroviária como simples condutor de segunda classe na Estrada de Ferro Pernambuco e, depois, sucessivamente, ajudante da Estrada de Ferro de Porto Alegre e Uruguaiana. Ocupou cargos de engenheiro-ajudante no prolongamento da Estrada de Ferro D. Pedro II, de diretor da Companhia de Obras Públicas de Minas Gerais, de engenheiro da Diretoria de Obras da capital de São Paulo, de consultor técnico do Ministério da Indústria e Obras Públicas, de Diretor da Estrada de Ferro Central do Brasil,no governo de Rodrigues Alves, quando Lauro Müller era ministro da Viação e Obras Públicas (1902-1906)"1, e de Presidente do Conselho

de classes - em especial, dos industriais - tentando inserir suas demandas nos quadros da sociedade política. No entanto, corresponde, ao mesmo tempo, a um locus de disputa hegemônica, onde se aglutinam agentes dotados de inserção determinada ria estrutura social vigente e que buscam defender seus interesses.

Em 20/01/1908, o Ministro Miguel Calmon, titular do MIVOP, solicitou ao Clube de Engenharia que organizasse um comitê, destinado a representar o país na "Internacional Electrotecnical Comission" (IEC), que tinha como objetivo promover a unificação da nomenclatura sobre grandezas e unidades elétricas e realizar a classificação dos aparelhos e das máquinas elétricas. Ata da $62^{\star 2}$ sessão do Conselho Diretor de 16/11/1908. Revista $n^{\circ}$ 26, de 1913: 218, 221-3.

to Diretor das Docas de Santos, Diretor da Cia. de Fósforos "Cruzeiro". Na CBEE, além de acionista, fez parte do Conselho Fiscal, em 1910.Arquivo Nacional - D.O. Abril de 1910, p. 3113. Ficha de associado do Clube de Engenharia em Schoppa (2004: 48).

${ }^{"}$ Lauro Müller era filho de comerciante de Santa Catarina; militar formado pela Escola Militar da Praia Vermelha; bacharel em Matemática e Ciências Físicas e Naturais; Presidente do Estado de Santa Catarina em 1889-1891; deputado constituinte em 1891; senador em 1900-1907 e 1917; Ministro da Viação e Obras Públicas 
Municipal, quando eram prefeitos Bento Ribeiro (1910-1914) e Rivadávia Corrêa (1914-1918) ${ }^{12}$. Portanto,já se nota a proximidade de Gabriel Osório de Almeida de um homem público que ocupou pastas importantes e determinantes para a expansão das atividades da CBEE, uma empresa de serviços públicos de eletricidade.

Outra trajetória importante a ser retomada é a de Jorge Street. Nas cido na cidade do Rio de Janeiro, em 1863, onde se destacou como um dos homens que mais lutaram pelo desenvolvimento industrial do país. Sua formação superior iniciou-se na Alemanha, onde fez Curso de Humanidades, e prosseguiu seus estudos no Brasil, formando-se médico pela Faculdade de Medicina do Rio de Janeiro.Voltou em seguida à Europa, em viagens de estudos, percorrendo vários centros científicos. Dedicou-se às atividades industriais, adquiriu e dirigiu as Fábricas de Juta São João, primeiro núcleo da Companhia Nacional de Tecidos de Juta e Rnak, no Rio de Janeiro e dirigiu a Cia. Docas de Santos. Transferindo-se para São Paulo, lá fundou as Fábricas Maria Zélia, Santana e Santa Celina. Além da atividade industrial, ocupou cargos importantes: em 1900, foi eleito para a diretoria da Sociedade Auxiliadora da Industrial Nacional; em 1904, tornou-se Secretário-Geral do Centro Industrial do Brasil (CIB); de 1905/1907, foi o primeiro secretário do CIB; em 1912, foi eleito presidente do CIB; em 1926, foi eleito Presidente da Associação Comercial de São Paulo; em 1931, foi nomeado Diretor Geral do Departamento Estadual do Trabalho e Consultor Técnico da Federação das Indústrias do Estado de São Paulo, da qual foi fundador, e fez parte da sua primeira diretoria (CARONE, 1978: 172) . $^{3 .}$.

Gabriel Osório de Almeida e Jorge Street (CORRÊA, 1996) também fizeram parte do Centro Industrial do Brasil (CIB), uma organização industrial de caráter permanente, que reunia empresas da capital e do

\footnotetext{
de 1902-1906, Ministro das Relações Exteriores de 1912-1917 e membro da Academia Brasileira de Letras (MENDONÇA, 1997:196).

Ficha de associado do Clube de Engenharia (SCHOPPA, 2004: 48). Foi também diretor da Escola Politécnica em 1896 (TURAZZI, 1989: 44).

Jorge Street, além de acionista, foi membro do Conselho Fiscal da C1SEE de 19101917, exceto em 1913. Arquivo Nacional - D.O., Abril de 1910-1917."Street ingressou no ramo da indústria têxtil dejuta como acionista da Cia. Fábrica São João no Rio de Janeiro, possivelmente recebendo herança de seu pai, Ernesto Diniz Street, engenheiro austríaco, que viera para o Brasil contratado pela firma Gaffrée-Guinle, para a construção de estradas de Ferro" (MATOS, 1996: 32).
} 
Estado do Rio de Janeiro e que foi, aos poucos, afirmando-se como representativa dos interesses da indústria de todas as partes do país (CARONE, 1978: 72) ${ }^{14}$. Segundo Leopoldi (1986: 66), "havia na Capital Federal (início do século XX), um movimento industrialista, e as vinculações das lideranças desse movimento com a política eram significativas", ou seja, a burguesia industrial se organizou em associações de classe, penetrando em organismos da sociedade política. E no volume I do Boletim do Centro Industrial do Brasil, eram definidos o sentido e o papel da entidade,

[...] se cada indústria, sob o ponto de vista técnico tem seus interesses à parte, há para todas um interesse comum, que cada dia mais se avoluma e que consiste em garantir o consumo interior das especialidades que são e devem ser produzidas no país. Nessa pugna colossal estão atualmente empenhadas todas as nações e nela carecemos também nós, industriais brasileiros, empenhar-nos ${ }^{15}$.

Jorge Street foi o primeiro secretário do Centro Industrial do Brasil, quando Inocêncio Serzedelo Corrêa era o presidente ${ }^{16}$, sucedendo-1he na presidência a partir de 1912, e tendo como seu primeiro secretário Gabriel Osório de Almeida.

Serzedelo estava presente também nas Comissões de Tarifa do Ministério da Fazenda e na Escola Politécnica do Rio de Janeiro, onde ensinava Economia Política e ocupava a presidência do CIB, quando foi nomeado por Nilo Peçanha,em 1909-1910, Prefeito do Distrito Federal, tendo realizado projetos de urbanização. Existiam entre Serzedelo, Street e Gaffrée vínculos de amizade, tanto que Gaffrée e Street foram teste-

\footnotetext{
${ }^{14}$ O CIB surgiu, em 1904, da fusão de entidades de classe: a SA1N e o Centro das Indústrias de Fiação e Tecelagem do Algodão do Rio de Janeiro, além de outras associações e empresas, tendo funcionado entre 1904 e 1931. Inclusive,Jorge Street, junto com Luís Rafael Vieira Souto,J. M. CunhaVasco e outros industriais participaram da fundação do centro.

is Boletim do Centro Industrial do Brasil.V, I, 1904-1905: 5.

"Serzedelo Corrêa era paraense e fazia parte do grupo de militares positivistas que colaboraram para a queda do Império. Com a Proclamação da República, ascendeu na carreira política, tendo sido, na década de 1890 , parlamentar e ministro de várias pastas (inclusive da Fazenda, em 1892/93). Presidiu a SAIN nos seus anos finais (1902/1904), ajudou a fundar o CIB, sendo seu presidente de 1904 a 1912.
} 
munhas do casamento civil de Serzedelo, em 1906 ${ }^{17}$. No entanto, sua aproximação com as lideranças industrialistas (Gaffrée e Street) ter-seiam dado muito mais por vinculações programáticas aos ideais defendidos pela fração de classe que passava a representar e organizar, do que por eventuais relações ou atividades econômicas. Serzedelo, um dos intelectuais que tentou pensar as questões econômicas brasileiras em termos gerais na Primeira República, preconizava como

[...] objetivos a formação e a consolidação do mercado interno - assegurado para o consumo da produção nacional de diversos gêneros agrícolas e industriais -, bem como o fomento e apoio, pelo Estado, do desenvolvimento industrial, entendido como capaz de garantir ao país a superioridade do estado econômico complexo.

E preconizava ainda uma política econômica que visava

[...] acima de tudo, à nacionalização progressiva das atividades econômicas realizadas no país, o que deve ser entendido tanto como retenção, no país, dos lucros das atividades econômicas levadas a efeito por estrangeiros, como, principalmente, enquanto nacionalização, das próprias atividades econômicas (C ORREA, 1996: 152).

Assim como o Clube de Engenharia, o CIB também estava muito próximo dos poderes públicos. Em 1905, em conferência realizada pela comissão de integrantes do CIB e o então Ministro daViação, Lauro Müller, foram assentadas as bases para a elaboração de uma estatística nacional, que seria realizada sob a direção deVieira Souto e consolidada, a princípio, sob o título "O Brasil em 1906."

Portanto, os empresários da CBEE estavam presentes em importantes entidades de classe, estabelecendo vínculos políticos fundamentais e compartilhando com outros tantos industriais, negociantes, engenheiros e intelectuais, determinadas alternativas políticas e econômicas para o país, no início do século XX, que necessariamente iam ao encontro dos seus interesses empresariais.

\footnotetext{
17 Ver certidão de casamento de 17/11/1906, constante do Inventário post-mortem de Inocêncio Serzedelo Corrêa, Arquivo Nacional.
} 


\section{A CBEE no Distrito Federal: luta pelo mercado da cidade do Rio de janeiro e aspectos sobre o setor da eletricidade no início do século $\mathrm{XX}$}

A Companhia Brasileira de Energia Elétrica (CBEE), fundada no Rio de Janeiro em $1^{\circ}$ de junho de 1909, por iniciativa dos Guinle, entre os quais Eduardo Guinle e Guilherme Guinle, filhos de Eduardo P. Guinle, deu continuidade aos negócios da firma Guinle \& Cia.

Em maio de 1903, no Rio de Janeiro, Adolf Aschoff, brasileiro, engenheiro e residente na cidade, e Eduardo Guinle, também brasileiro, engenheiro, mas residente ainda nos Estados Unidos, representado por seu pai, Eduardo P. Guinle, brasileiro, negociante, residente na cidade, se fizeram sócios e fundaram a Aschoff \& Guinle, objetivando importar, exportar e consignar equipamentos elétricos ${ }^{18}$. No entanto, em 24 de março de 1904, foi arquivada naJunta Comercial do Rio de Janeiro a escritura de contrato da Sociedade Comercial Guinle \& Cia., que iria continuar o negócio da Aschoff \& Guinle ${ }^{19}$.

Assim, muito antes da fundação da Guinle \& Cia. pelos irmãos Eduardo, Guilherme e Carlos Guinle, o interesse de Cândido Gaffrée e Eduardo P. Guinle - sócios da Companhia Docas de Santos e, posteriormente, acionistas da CBEE - pelas atividades de energia elétrica remonta a 1899. Naquele ano, adquiriram uma queda d'água no rio Paquequer, com o objetivo de construir uma hidrelétrica para fornecer eletricidade à cidade do Rio de Janeiro, mas o empenho na construção do porto de Santos teria adiado seus projetos até 1901, quando Gaffrée \& Guinle obtiveram autorização para instalar a hidrelétrica de Itatinga, destinada a fornecer energia elétrica para a Cia. Docas de Santos (LAMARÃO, 1997: 215-6).

Entretanto, os empreendimentos do grupo Gaffrée \& Guinle, nos negócios relativos à produção, à transmissão e à distribuição da eletri-

Arquivo Nacional - Junta Comercial. L 421 R53050 S2 (1903). No entanto.já em 1892 surge a firma Mitchell \& Aschoff, com o objetivo de importar equipamentos de produção e distribuição de energia elétrica, fabricados pela General Electric (USA), mas esta se desfaze Mitchell liga-se ao grupo Mackenzie e Pearson e Aschoff, a Eduardo Guinle, na firma Aschoff \& Guinle (HONORATO, 1990).

Arquivo Nacional - Junta Comercial. L 431 R 54088 (1904). Adolf Aschoff morreu em 10/02/1904 e, aí, a firma que tinha com Eduardo Guinle foi liquidada. 
cidade no Rio deJaneiro e, em especial, no Distrito Federal, começaram a se estabelecer apenas em 1906, quando foi iniciada a obra de construção da usina de Piabanha, em Alberto Torres, então município de Paraíba do Sul. Anteriormente, a empresa somente chegou a fazer estudos para a exploração do Rio Paraíba do Sul e outros rios fluminenses para representar a General Electric (GE) no Brasil, além de executar projetos e construir linhas de transmissão para terceiros ${ }^{20}$.

Paralelamente aos estudos, à execução de projetos e à construção da Usina de Piabanha pela empresa dos Guinle, Frederick Pearson e Alexander Mackenzie, associados ao capitalista norte-americano Percival Farquhar, constituíram a Rio Light, primeiro em Nova Jersey, em maio de 1904, que, incorporada em Toronto, Canadá, emjunho, teve sua constituição definitiva. Autorizada a funcionar no Brasil em maio de 1905,já em dezembro do mesmo ano começou a construção da hidrelétrica de Fontes, no ribeirão das Lajes, no município fluminense de Piraí, concluída, assim como a usina de Piabanha, em 1908 (LAMAR ÃO, 1997: 208).

Logo, o Distrito Federal, que contava com um enorme mercado (LOBO, 1986: 56) ${ }^{21}$, apresentando uma promissora demanda potencial para a instalação de serviços de energia elétrica nos campos dos transportes públicos e da iluminação pública e particular, e também no da indústria, vai ser disputado por duas grandes empresas de serviços públicos, no início do século XX, e vão ter que contar não só com seus recursos econômicos, mas também com os aspectos legais do setor da eletricidade no Brasil e com a força política de seus empresários.

É importante ressaltar que este período da história do país correspondeu a um momento de transformações em que, na transição brasileira rumo ao capitalismo, a implantação da infra-estrutura para comercialização do café e dos serviços urbanos teve origem na exportação de

\footnotetext{
Os trabalhos de aproveitamento das quedas do Piabanha começaram em 1906 e ficaram prontos em 1908. A data oficial da inauguração foi o dia 9/11/1908, mas a subestação de Niterói só foi concluída em 1909. O potencial hidráulico das quedas do Piabanha e seu afluente, o Fagundes, situados a pouco mais de $100 \mathrm{~km}$ da capital federal, seria de $36.750 \mathrm{kw}$. CME. A Usina de Piabanha: contexto histórico. Coordenadoria de Pesquisa. Xerox, s/d.

${ }^{2}$ A região fluminense destacava-se por ter uma grande atividade portuária, especializando-se na função de receptora e distribuidora de matéria-prima e maquinário para a indústria. A alfândega tinha uma grande arrecadação e a região era um grande centro financeiro.
} 
capitais das áreas centrais do imperialismo e concorreu para a reafirmação da vocação agrícola do país e para o "auge da economia de exportação" (OLIVEIRA, 1975). Correspondendo politicamente a um momento de intensificação dos conflitos de interesses econômicos corporativos, que assumem forma de disputa na própria sociedade civil (MENDONÇA, 1997), na qual os industriais e os negociantes, sejam eles intitulados nacionais ou estrangeiros, além de outras frações de classes, buscaram defender seus interesses, através das entidades de classes e também na sua aproximação com os ocupantes dos órgãos públicos. Portanto, muitos dos empresários da Guinle \& Cia./CBEE atuavam em organismos da sociedade civil, buscando defender seus negócios, tecendo alianças, que serão importantes no seu processo de disputas contra a empresa Rio Light pelo controle do mercado no Distrito Federal.

Havia, no início do século XX, na cidade do Rio de Janeiro, duas empresas controlando os serviços de eletricidade: a concessão Reid primeira concessão municipal referente ao fornecimento de energia elétrica ao Distrito Federal, datada de 1899, em que a William Reid \& Cia. tinha o direito de gerar e distribuir eletricidade de origem hidráulica, com exclusividade até 1915, e sem exclusividade até 1950; e a Societé Anonyme du Gaz (SAG), que tinha o direito exclusivo de fornecer gás canalizado à cidade do Rio de Janeiro para os serviços de iluminação pública ou quaisquer outros usos até $1915^{22}$. Logo, tanto a exclusividade da Reid quanto da SAG terminaria em 1915 (LAMARÃO, 1997).

No entanto, a legislação municipal - decreto municipal $n^{\circ} 1.001$, de 21 de outubro de 1904 - criada no governo Pereira Passos ${ }^{23}$, proibia a concessão de privilégio exclusivo para qualquer aplicação de energia elétrica no Distrito Federal, apoiando então o ideal de livre concorrência, o que seria bom, tanto para a Rio Light quanto para a Guinle \&

\footnotetext{
Uma revisão contratual, concretizada pelo Decreto $n^{\circ} 3.329$, dejulho de 1899 , concedeu à SAG o privilégio para a iluminação da cidade por gás corrente ou eletricidade. Houve, nesse momento, distinção entre a iluminação pública e a particular. O privilégio com relação à primeira terminaria em 1945 e, com relação à segunda, em 1915. MEMÓRIA DA ELETRICIDADE. Debates parlamentares sobre energia elétrica na Primeira República. O processo legislativo. Rio de Janeiro: Memória da Eletricidade, 1990 (texto de Paulo Brandi de Barros Cachapuz), p. 158. Sobre a renovação urbana da cidade do Rio de Janeiro no início do século XX, ver Jaime Benchimol (1992).
} 
Cia., interessadas no mercado carioca. Mas a SAG, recorrendo da decisão judicial, tomada em setembro de 1904, em que havia triunfado a ação antimonopolista da Companhia de Ferro-Carril doJardim Botânico (CFCJB), contrata o grandejurista Ruy Barbosa para estudar o assuntojudicial e seu parecer, contrário à livre concorrência, reverte o processo, transformando a SAG em vencedora, ou seja, monopolizava os serviços de iluminação na cidade (LAMARÃO, 1997).

Aqui, cabe salientar aspectos da institucionalização dos serviços de eletricidade no Brasil desse período. O ordenamentojurídico que determinava parte do Estatuto legal que regeu o setor elétrico, outorgou enormes poderes aos estados e aos municípios e, ao mesmo tempo, limitou a interferência da União na indústria da eletricidade (geração, transmissão e distribuição), abrindo espaços de negociação entre os poderes concedentes da época e as empresas concessionárias. Na prática, eram os municípios os verdadeiros poderes concedentes dos serviços de distribuição de eletricidade, que faziam contratos com várias empresas de serviços públicos sem, no entanto, conseguir demarcar muito claramente competências, áreas de atuação, direitos, etc, o que gerava uma série de problemas para as sociedades de eletricidade e também para os municípios.

No caso do Distrito Federal, além deste agravante, havia também o fato de que a cidade, em função da sua condição de capital federal ${ }^{24}$, foi administrada simultaneamente pelos governos central e municipal, pois o governo federal, por intermédio do Ministério da Indústria,Viação e

\footnotetext{
${ }^{24}$ Pela Constituição de 1891, o antigo Município Neutro da Corte foi transformado em Distrito Federal, devendo permanecer como sede do Estado nacional. A Lei Orgânica do Distrito Federal, aprovada em 1892, instituiu um Conselho Municipal, com funções legislativas, e a prefeitura do Distrito Federal, com atribuições executivas. O conselho seria formado por 27 intendentes, eleitos pelo voto popular, e o prefeito seria nomeado pelo presidente da República, ad referendum do Senado Federal. Ao Senado competiria também decidir acerca dos vetos do prefeito às resoluções do Conselho Municipal. Com relação ao serviço de iluminação, a Lei Orgânica determinou a sua transferência para a esfera municipal, mas esta não foi levada a efeito. Portanto,o governo federal continuou como poder concedente e fiscalizador do serviço de iluminação e a municipalidade administrava as atividades relativas ao fornecimento de eletricidade. MEMÓRIA DA ELETRICIDADE. Debates parlamentares sobre energia elétrica na Primeira República. O processo legislativo. Rio de Janeiro: Memória da Eletricidade, 1990 (texto de Paulo Brandi de Barras (achapuz), p. 157-158.
} 
Obras Públicas (MIVOP), atuava como o poder concedente e fiscalizador dos serviços de iluminação e, em relação ao fornecimento de energia elétrica, a municipalidade atuou com plenos poderes, criando-se, assim, uma situação de dualidade no que concerne aos serviços públicos de eletricidade, na qual a legislação e os atos administrativos a eles referentes refletiram decisões de âmbito municipal e federal (LAMARÃO, 1997). Portanto, uma situação complexa, e a disputa Light x CBEE vai-se dar neste ambiente jurídico confuso.

Já em 1904, e ainda não autorizada a funcionar no Brasil, a Rio Light comprou a concessão de William Reid \& Cia. e entrou com pedido de autorização, no MIVOP, para funcionar no Brasil. Nesse momento, duas questões devem ser levadas em consideração para a análise do processo de disputa. Primeiro, indo ao encontro do que estabelecia o decreto municipal n 1.001, de 21/10/1904, o então Ministro do MIVOP, Lauro Muller, assinava o Decreto federal $\mathrm{n}^{\circ} 5.407$, de 27/12/1904, regulamentando o aproveitamento da força hidráulica para a transformação em energia elétrica aplicada aos serviços federais. O governo federal passava a ter o direito de determinar os trechos de rios a serem explorados e os limites máximos e mínimos das instalações. Também permitia à União contratar qualquer empresa para fornecer energia elétrica aos serviços sob seu controle e, além disto, os excedentes de energia produzidos por estas empresas poderiam ser empregados na lavoura, na indústria ou para outros fins. Portanto, abria-se a possibilidade, novamente, de concorrência.

Segundo, o mesmo Lauro Müller negava, em março de 1905, o primeiro pedido feito pela Light para funcionar no Brasil, sendo concedido apenas em maio de 1905, após interferência do Embaixador norteamericano, Lloyd Griscom. As acusações ácidas no jornal carioca $O$ Correio da Manhã acerca do episódio ${ }^{25}$ afirmavam abertamente que Lauro Müller, em cargo público, defendia interesses particulares do grupo Gaffrée/Guinle. O editorial do Correio da Manhã de 25/03/ 1905, intitulado "Corja de Gatunos", dizia:

\footnotetext{
25 Lamarão afirma que o Jornal do Commercio, secundado pelos jornais A Notícia e Gazeta de Notícias, foram, nesta contenda, porta-vozes da Guinle \& Cia., enquanto os jornais O País e O Correio da Manhã defenderiam a Rio Light (LAMAR Ã O, 1997:214).
} 
Aproximam-se certos fornecimentos necessários à Avenida Central, de que se quer encarregar a casa Gaffrée e Cia. De que depende o Sr. Lauro Müller.Temem a concorrência da Light \& Power, que explora a indústria de fornecimento da energia elétrica e que ficará afastada sob o pretexto da falta de licença para funcionar no Brasil. Isto é simplesmente imoral e vergonhoso, toda a gente sabe que o Sr. Gaffrée faz do ministro Lauro Müller o mesmo que fazia do Sr. Amaral, quando diretor do Bando do Brasil: dominava-o inteiramente, porque o traz constantemente preso [...].

A quatro de março, fazem hoje vinte e um dias, anunciamos nestas colunas, sob o título presago - presago e profético - ai de nós! Negociata Planejada, o plano do Sr. Cândido Gaffrée, ministro de fato da Indústria e Viação da República do Brasil, com um caixeiro, ministro in nomine, que responde pelo nome de Lauro Müller (HONORATO, 1990).

Claro está que Lauro Müller criou possibilidades, com o Decreto federal $n^{\circ}$ 5.407, de outras empresas, além daquelas que tinham exclusividade para os serviços de fornecimento de energia e iluminação na cidade, disputarem estes mesmos serviços, podendo ser a Light, a Guinle \& Cia., ou outra qualquer. Porém, ao mesmo tempo, tentou impedir o funcionamento da empresa que ameaçava as intenções do grupo Gaffrée/Guinle. Logo, se conseguisse impedir a Light de funcionar no Brasil, as chances de o grupo Gaffrée/Guinle conquistar o mercado eram enormes. Concretamente, durante a gestão de Lauro Müller no MIVOP, este mantinha relações próximas com o grupo de Gaffréel Guinle, entretanto, a Guinle \& Cia. em nada conseguiu avançar como empresa de eletricidade na cidade do Rio dejaneiro, até porque ainda estava construindo seu parque gerador (LAMAR ÃO, 1997: 215).

Em meio a este primeiro embate, em que em uma pasta da esfera federal - o MIVOP - o grupo Gaffrée/Guinle teria tido apoio, a Light dá continuidade à sua estratégia para conquistar o mercado carioca. Ainda em 1905, adquire as concessões ligadas aos serviços de iluminação elétrica pública e particular, quando passou a controlar a $\mathrm{SAG}^{26}$.

\footnotetext{
Os serviços de bondes foram conseguidos entre 1905 e 1907, completando o domínio sobre os sistemas de bondes da cidade em 1910. CME.A Cerje a História da Energia Elétrica no Rio de Janeiro. Coordenadoria de Pesquisa. Rio de Janeiro: CME, 1993:77.
} 
Portanto, de certa forma, em 1905, a situação estava estabelecida: a Light havia adquirido as concessões dos serviços de eletricidade, todos os serviços contratados pela municipalidade, e a Guinle \& Cia., depois CBEE, apoiando-se no decreto municipal $\mathrm{n}^{\circ} 1.001$ - já derrotado no julgamento do caso da SAG - e também no decreto federal $n^{\circ}$ 5.407, pretendia disputar o mercado. Portanto, os Guinle mantinham a argumentação frente à legislação livre-concorrencial, tanto municipal, quanto federal, que apontava para a possibilidade da existência de mais de uma empresa de serviços públicos de eletricidade na Capital Federal.

A partir daí, ainda em 1905, a Guinle \& Cia. recebeu as concessões do governo fluminense para o aproveitamento hidráulico dos rios Piabanha e Fagundes; em 1907, conseguiu, através do decreto federal $n^{\circ} 6.367$, autorização para participar do fornecimento de energia elétrica para os serviços públicos federais instalados na cidade do Rio de Janeiro, através da energia produzida pela hidrelétrica de Piabanha; pelo decreto federal $n^{\circ}$ 5.646, de 1905, conseguiu o direito de isenção de tarifas aduaneiras e o de desapropriação de terrenos para empresas hidrelétricas constituídas para fins de utilidade pública; ainda em 1905, pelo decreto $\mathrm{n}^{\circ}$ 6.732, o governo federal aprovou o projeto da linha de transmissão de energia elétrica da Usina de Piabanha até o Distrito Federal; em 1908, conseguiu seu primeiro contrato de fornecimento de energia elétrica na cidade do Rio de Janeiro, celebrado com a Estrada de Ferro Central do Brasil (CME, 1993: 79). Portanto, estava preparada para fornecer energia à Capital Federal, faltando, no entanto, a autorização para o serviço no mercado tão desejado ${ }^{27}$.

Mas a entrada do general Souza Aguiar (1906-1909) na prefeitura da cidade do Rio de Janeiro teria sido importantíssima para a Light - momento em que a empresa teve atendidas suas reivindicações com relação aos serviços públicos de eletricidade (McDOWALL, 1988: 146-9). E, ainda, Nilo Peçanha (1904-1906) e Alfredo Backer, (1907-1910), Presidentes do Estado do Rio de Janeiro, seriam a favor da Light. Inclusive, segundo Lamarão (1997:217), Nilo Peçanha era um admirador confesso da empresa estrangeira.

A Guinle \& Cia. vai fornecer energia também para Niterói, Petrópolis, São Gonçalo e Magé. 
Analisando as mensagens feitas por Alfredo Backer à Assembléia Legislativa do Estado do Rio de Janeiro, percebe-se que ele até poderia ter cooperado com a Light na sua gestão, pois, nas suas mensagens, fica clara a preferência por ela. A esta empresa faz vários elogios, descreve seus investimentos, destaca sua importância, enquanto se limita a registrar a existência da CBEE. Com relação à afirmação feita sobre Nilo Peçanha, suas mensagens à Assembléia não confirmam esta preferência, especialmente a proferida em 01/08/1906, onde o texto é muito "bem equilibrado" e as informações são dadas sobre as duas empresas ${ }^{28}$.

Lamarão (1997:216) também afirma que,durante a gestão de Serzedelo Corrêa na prefeitura da cidade do Rio de Janeiro, a Guinle \& Cia., agora CBEE, teria recebido apoio aberto. Concretamente, a afirmação de Lamarão se comprova, pois foi na gestão Serzedelo que a CBEE assinou com a prefeitura do Distrito Federal um contrato para ocupação das ruas e das praças da cidade do Rio de Janeiro, bem como os caminhos públicos da zona rural deste Distrito, com canalizações para distribuição de energia elétrica para consumo público em geral, nos termos do decreto $\mathrm{n}^{\circ} 1.001$, de 21/10/1904, cuja cláusula segunda estabelecia:

[...] o prazo para inauguração da distribuição de energia elétrica corresponde ao tempo que medeia entre a data da assinatura deste contrato e o dia sete de junho de mil novecentos e quinze, e será improrrogável, salvo por motivo de força maior ${ }^{29}$.

Na Assembléia da CBEE, realizada em 1910, a fila do presidente da reunião, Cândido Gaffrée, foi bastante emblemática, pois se congratulava com os acionistas pelo desenvolvimento e pela prosperidade da companhia e, sobretudo, pela consecução, dentro da lei, da concessão para distribuição de energia no Distrito Federal, cuja outorga, afirmava ele, teria resultado de "um ato que patenteou a coragem cívica e obediência à lei, por parte do atual prefeito municipal". Referia-se a Serzedelo. Inclusive, elogiava também Nilo Peçanha, presidente da República. Portanto, ficaram claras as boas relações e os bons resultados destas relações para a empresa, pois 1915 corresponderia ao prazo em que expirava a exclusi-

MALER J - 1904-1910.

CONTRATO ENTRE A PREFEITURA DO DiSTRITO FEDERAL E A GBEE, 27/04/1910. Rio de Janeiro: Papelaria Americana. 
vidade dos canadenses - Concessão Reid de distribuição de energia hidrelétrica para suprimento de força.

Outro momento favorável à CBEE teria sido quando Francisco de Oliveira Botelho chegou à presidência do Estado (1911-1912). O secretário particular do presidente era filho de Gabriel Osório de Almeida, Osório de Almeida Filho. Em termos práticos e concretos, o que podemos afirmar, baseados nas mensagens à Assembléia Legislativa do Estado do Rio de Janeiro, é que o presidente via nos negócios feitos com a Light grandes prejuízos para o Estado. Criticou algumas obras da Light, lamentou a não obrigatoriedade de a Light fornecer energia elétrica para o Estado, enfim, criticou os contratos com a empresa ${ }^{30}$.

No entanto, enquanto as iniciativas do grupo Gaffrée/Guinle esbarravam nas resistências da prefeitura do Distrito Federal, especialmente durante o governo Souza Aguiar, a Light ampliava suas vantagens. Mackenzie negociou a revisão do contrato de maio de 1905, formalizada em junho de 1907, quando a Light conseguiu ampliar seu prazo de concessão para distribuição de energia elétrica no Distrito Federal, na base da não-exclusividade, de 1950 para 1990. No mesmo ano, após a Guinle \& Cia. ter conseguido, pelo Decreto ${ }^{\circ} 6.732$, autorização do governo federal para assentar linhas de transmissão de energia elétrica dentro do Distrito Federal, para suprimento de força motriz aos serviços públicos federais, o prefeito Souza Aguiar negou a autorização para que fossem assentadas as torres de transmissão da Guinle \& Cia. (LAMAR ÃO, 1997:226).

Os advogados da CBEE, acusando conflito de jurisdição, levaram a questão para os tribunais, que negaram o conflito, dando vitória aos canadenses. Além de tudo isto, ainda em 1909, a municipalidade obteve autorização para rever a concessão da SAG, que foi estendido de 1915 para 1945, com a exclusividade assegurada até 1915. E o Supremo Tribunal Federal, em 1915, acabou atendendo parcialmente às posições de Ruy Barbosa, advogado da Light, reconhecendo que o suprimento de energia elétrica era da alçada municipal.

Portanto, a CBEE teve "aliados" nas três instâncias do poder: Lauro Müller, Ministro do MIVOP; Oliveira Botelho, Presidente do Estado e

MALERJ - 1910. 
Serzedelo Corrêa, Prefeito do Distrito Federal ${ }^{31}$. Cabe ressaltar também que, durante a gestão de Miguel Calmon Du Pin e Almeida no MIVOP, especialmente em 1907, a Guinle \& Cia. obteve grandes vantagens ${ }^{32}$. No entanto, a estratégia da Light, ou seja, a compra das empresas concessionárias dos serviços de iluminação e fornecimento de energia elétrica na Capital Federal, contratados com a municipalidade, mostra o quanto as prefeituras municipais e suas câmaras eram importantes como poderes concedentes dos serviços públicos, além de mostrarem o poder dos contratos. Mesmo amparada nos decretos $\mathrm{n}^{\circ}$ 1.001 - municipal - e ${ }^{\circ} 5.407$ - federal - a CBEE não conseguiu furar o bloqueio da Light.

\section{A CBEE na cidade de São Paulo: projeto de expansão da empresa nacional e disputa política na Câmara Municipal}

A história da Companhia Brasileira de Energia Elétrica no Estado de São Paulo pode ser considerada mais antiga que sua própria existência. A disputa de Eduardo P. Guinle e Cândido Gaffrée por concessões de serviços de energia elétrica em São Paulo só seria verificada a partir de 1909, porém,já no ano de 1888, por meio da empresa Gaffrée, Guinle \& Cia., os empresários conquistavam a concessão do Porto de Santos, formando pouco mais tarde a imponente Companhia Docas de Santos. Os empresários que mantinham seus negócios no Rio de Janeiro chegavam a São Paulo controlando a fonte de escoamento do café paulista, que logo se tornou o principal produto de exportação brasileiro e impulsionou transformações determinantes na sociedade paulista. Com relação aos serviços de energia elétrica, apenas anos mais

\footnotetext{
Cabe ressaltar, no entanto, que, nesse momento, a Lightjá havia comprado as concessões dos serviços públicos de eletricidade na cidade, feitas pela municipalidade. Pelo Decreto Federal no 5.646 foi regulamentada e enquadrada na categoria pública; pelo Decreto Federal $n^{\circ} 6.732$ foi autorizada a assentar linhas de transmissão de energia elétrica dentro do Distrito Federal para suprimento de torça aos serviços públicos federais; pelo Decreto Federal $n^{\circ}$ 7.437, foi autorizada a estabelecer cabos submarinos para a transmissão de energia entre Niterói e o Rio de Janeiro, destinada a auxiliar aquela que já vinha sendo construída entre a usina de Piabanha e a capital federal.
} 
tarde o setor teria um fim comercial para Guinle \& Co. (posteriormente CBEE) e, para tanto, a empresa deveria combater o monopólio que vinha sendo criado pela empresa canadense The São Paulo Light \& Power Company Ltd.

O fluxo de exportação e importação de produtos no Porto de Santos crescia de maneira suntuosa no último quarto do século XIX, demandando um complexo de reformas portuárias, que dificilmente poderiam ser financiadas pelo Império. Assim, desde 1869, por determinação do decreto ${ }^{\circ}$ 1.746, a jurisprudência dos portos brasileiros estaria nas mãos do Governo Imperial (e, mais tarde, Federal), enquanto a exploração seria transmitida por concessões para empresas privadas (HONORATO, 1996:86-90).Esta medida centralizadora e privatista visava a ampliação e a modernização dos portos e, no caso do Porto de Santos, obteve êxito com as profundas reformas comandadas pela Companhia Docas de Santos. Por mais que parecesse necessária a presença de investimentos privados para as obras de melhoramento do Porto de Santos, alguns políticos, como os Deputados do Estado de São Paulo Coelho Rodrigues e Sr. Lourenço de Albuquerque, se colocavam contrários à concessão, de caráter monopolístico, passada para o grupo de José Pinto de Oliveira, Candido Gaffrée e Eduardo P. Guinle ${ }^{33}$. Entretanto, a vitória dos empresários viria com a determinante defesa elaborada pelo então Ministro da Agricultura Antonio Prado, que, em discurso final, dizia:

Tenho dito o que é necessário para mostrar que o acto do Governo, escolhendo a proposta Pinto de Oliveira e outros para a construcção do caes de Santos, baseou-se em que esta proposta era a única aceitável, e que estando nestas condições não contrariava os interesses commerciaes do porto de Santos e da Província de São Paulo.

Formavam então a Gaffrée, Guinle \& Cia., empresa concessionária do Porto de Santos e registrada na Junta do Commercio, em 1888, com os seguintes membros: José Pinto de Oliveira (450 contos de réis), Cândido Gaffrée (1.000 contos de réis), Eduardo Guinle (500 contos de réis), Dr. Alfredo CamiloValdetario (450 contos de réis), Benedito Antonio da Silva (500 contos de réis), FranciscoJustiniano de Castro Rabelo (500 contos de réis) e Hippólito Veloso Pederneiras (150 contos de réis), somando, no total, 4.000 contos de réis, quantia considerável em comparação com as receitas do ano de 1889 das Províncias do Rio de Janeiro, de 4.399 contos de réis, e de São Paulo, de 4.089 contos de réis (HONORATO, 1996: 111 e 115). 
Depois de tudo quando se tem dito contra esse acto do Governo, se tivesse ainda de resolver novamente a questão declaro que escolheria a mesma proposta, nas mesmas condições em que foi approvada, convencido como estou de que prestei com isto mais um importante serviço a minha Província (HONORATO, 1996:110).

Inserido num importante debate sobre as concessões dos serviços públicos, o ainda Ministro da Agricultura Antonio Prado não fazia idéia de que, anos mais tarde e, agora, como Prefeito da Cidade de São Paulo, teria que novamente se posicionar sobre a presença de empresas privadas no fornecimento de serviços públicos. Prefeito entre 1899 e 1910, Antonio Prado foi quem autorizou, no seu primeiro ano de governo, o funcionamento da São Paulo Light na prestação de serviços de transporte urbano, distribuição de iluminação e energia para indústrias. No período de chegada da Light no Brasil, o grupo de Guinle ainda não apresentava interesses consolidados no setor elétrico, o que somente se verificaria com a representação da empresa americana GE no Rio de Janeiro e em São Paulo, no ano de 1903.

Político participativo, Antonio Prado era também influente empresário na economia paulista, como produtor de café e acionista em estradas de ferro, bancos e empresas de serviços urbanos, como a Companhia Viação Paulista, empresa responsável pelo transporte urbano na cidade de São Paulo (SILVA, 1986: 47). Assim, Antonio Prado estava mais que desconfiado dos empresários lightianos Frederick Pearson e Alexander Mackensie, considerando-os "American bluffers" (McDowALL, 1988: 44) e, por isto, se questionava quanto à abertura do mercado paulistano para uma empresa estrangeira. Independentemente da vontade do prefeito, a Light já estava autorizada a funcionar no país pelo decreto do Presidente da República Campos Sales, de 17 de julho de 1899, e por aquisição da concessão de Gualco e Souza para o transporte coletivo na cidade de São Paulo, de 16 de dezembro de 1898 (SOUZA, 1982:28-9). E, tão logo a empresa canadense iniciou sua operação em São Paulo, partiu para a consolidação de monopólios no mercado paulista, passando por cima de leis, como ao questionar o contrato de unificação da Viação Paulista, que dava privilégio do transporte à empresa nas áreas já atendidas. A Light não somente conseguiu vitórias nos tribunais com o advogado Carlos de Campos, como forçou o fechamento daViação Paulista pela aquisição de suas dívidas (SILVA, 1986: 34-5). 
Ainda neste período, a Light, por intermédio da compra da maioria das ações da Companhia Água e Luz, em Assembléia Geral, realizada no dia 31 de maio de 1900, formava uma diretoria própria para controlar os serviços de eletricidade.A nova diretoria era composta pelo advogado da Light Carlos de Campos, pelo ex-presidente do Estado de São Paulo, Fernando de Albuquerque e pelo engenheiro e amigo de Pearson, Octavio Pacheco e Silva (SOUZA, 1982: 35 ) $^{34}$. A diretoria tinha a particularidade de ser comandada por membros da elite paulista, medida que aparentemente se tornava uma estratégia da empresa canadense para compor com grupos políticos locais. Esta lógica era reafirmada no primeiro relatório anual da São Paulo Light, remetido para o Canadá em 1902, em que os diretores canadenses no Brasil pediam a distribuição das novas ações ${ }^{35}$ da empresa para cidadãos relevantes: it is their desire (dos diretores) to offer such shares for subscription by prominent citizens of São Paulo, as it is felt that the Company's interests will be well served by increasing the amount of our capital owned locally in Brazil (LIGHT, 1902: 7).

O mecanismo de composição política com a elite paulista era muito eficiente para possibilitar maior trânsito dos interesses da Light nos meios políticos. Os investimentos crescentes,juntamente com o poder político que a empresa canadense vinha consolidando, não só na cidade

Carlos de Campos foi deputado estadual pelo PRP, eleito em 1896 e reeleito no mandato seguinte. Secretário da Pasta de Justiça e da Agricultura do Presidente Campos Sales, foi ainda líder político da bancada paulista no Legislativo e Presidente do Estado de São Paulo entre 1924 e 1927, além dejornalista do Correio Paulistano. Filho de Bernardino às Campos, influente membro do Senado de São Paulo na legislatura entre 1907-1915 e Presidente do Estado entre os anos de 1892-1896 e 1902-1904. A família tinha forte presença nas decisões políticas e foi por intermédio de seu sogro, Antônio Augusto de Souza, que Carlos de Campos viabilizou a transmissão da concessão de Gualco e Souza para a Light. Fernando Preste de Albuquerque (pai de Júlio Preste) foi deputado estadual em 1892, federal em 1896 e Presidente do Estado de São Paulo entre 1898 e 1900, no lugar de Campos Sales. Voltou para a Câmara Federal até 1912, quando se elegeu para o Senado do Estado, entre 1912 e 1924, tornando-se então vice-presidente do Estado no mandato de Carlos de Campos (ALVES, 1986: 125-6 e 154-6).

Em abril de 1902, o capital da empresa era aumentado de 6 milhões de dólares para 7 milhões. Deste aumento de 1 milhão, 400 mil dólares foram transformados em ações ordinárias, destinadas a que membros da elite paulista pudessem comprar (LIGHT, 1902). No ano de 1899, os 6 milhões correspondiam a 36.000 contos de réis, praticamente a receita do Estado de São Paulo, equivalente a 39.500 contos de réis (SOUZA, 1982: 39-40). 
de São Paulo como até mesmo no Distrito Federal, com a ampliação da empresa para o Rio de Janeiro no ano de 1905, pareciam dar condições para a empresa assumir o monopólio dos serviços públicos nos principais mercados brasileiros. Para questionar este poder que vinha sendo estabelecido, entrava em cena no mercado de energia elétrica a Guinle \& Co. Em São Paulo, vinculada à Companhia Docas de Santos, a família Guinle pretendia aproveitar o excedente de energia elétrica que era produzido para a utilização no Porto de Santos, a fim de fornecer eletricidade para a capital paulista por preços módicos.

As concessões estaduais e federais para o aproveitamento de quedas d'águas para fins energéticos já haviam sido adquiridas pela CBEE (Guinle \& Co.) antes de 1905.0 passo mais importante para a empresa era convencer as instituições municipais de que o projeto elaborado por Guinles beneficiaria a população de São Paulo. Os empresários nacionais justificavam que, por meio do sistema de livre-concorrência e pela entrada de mais uma companhia no fornecimento de energia elétrica para a cidade, além de conseguir abastecer as regiões ainda carentes do serviço de eletricidade com maior agilidade, a população poderia beneficiar-se com a redução de tarifas.

Segundo a lei federal de 1891 , no artigo 72 e $\$ 24$, ficava estabelecido o livre exercício de empresas nos setores industriais e comerciais em todo o território brasileiro (BARROS, 1982: 25). Conseqüentemente, esta lei garantia o direito da entrada da CBEE no mercado paulistano. Contudo, por mais que a lei fosse federal, tanto o governo federal como o estadual, tinham limites na orientação para o estabelecimento de empresas no fornecimento de serviços públicos, cujas concessões eram autorizadas e controladas pelo município, da maneira que melhor lhe conviesse. Assim, no ano de 1906, o governo do Estado de São Paulo, seguindo recomendações da Câmara Municipal da capital paulista, decretava a lei $n^{\circ} 1.038$, considerando que os vereadores tinham

[...] a faculdade de conceder privilégios para a construção de obras e serviços, que dependam de grandes capitaes, e sem dúvida, está nessas condições os serviços de energia electrica, para o uso commum dos habitantes praticado nesta cidade (São Paulo) pela Light and Power ${ }^{36}$.

Assembléia Legislativa. Parecer $n^{\circ} 78$, de 1906. 
Logo nas primeiras semanas do ano de 1909, a CBEE, sob comando da família de Eduardo Guinle, iniciou sua ofensiva para conquistar parcela do mercado paulista. Eram patentes a reclamação e a reivindicação existentes sobre o crescimento do consumo de energia elétrica e a aparente dificuldade da Light em acompanhar a demanda. Em bairros mais afastados, como a Penha, campanhas nos meios de comunicação eram feitas para exigir medidas do poder público, como na notícia do Commercio de São Paulo:

A Penha, como se sabe, é illuminada a kerosene, illuminada? Não; a Penha,de há muito,permanece em trevas... com sua illuminação a kerosene. Essa illuminação é feita por conta da municipalidade, quando tal serviço compete ao governo, desde que começou a arrebatar ali o imposto predial ${ }^{37}$.

Existiam ainda questionamentos provenientes de industriais que dependiam do aumento do fornecimento de energia para continuar produzindo, como no caso das fábricas de juta de Jorge Street ${ }^{38}$, e também daqueles industriais que defendiam a possibilidade de suprir sua própria energia elétrica, como no caso da Klabin:

Os Srs. Klabin Irmãos \& Comp., em defesa dos seus direitos e da classe dos industriais paulistas, dirigiram à municipalidade da capital a seguinte argumentação: (...) Referimo-nos à ressalva, que deve ficar expressa no contrato do direito dos industriais já estabelecidos ou que vierem a se estabelecer na cidade ou no município, de poderem trazer das instalações próprias (...) a energia electrica de que carecem para seus próprios estabelecimentos industriais ${ }^{39}$.

Antonio Prado, que era grande entusiasta das melhorias da cidade e ideologicamente vinculado à defesa do liberalismo, imaginava que a entrada de uma nova empresa poderia auxiliar o processo de urbaniza-

OCom mercio de São Paulo, 6 de agosto de 1910.

s $\mathrm{O}$ empresárioJorge Street era ligado ao grupo Guinle, como acionista em parte dos negócios da família. Em diversosjornais da época, é recorrente encontrar artigos de Street em defesa do capital nacional e atacando a empresa canadense Light (TEIXEIRA, 1990).

"Câmara Municipal, 23 de dezembro de 1908. 
ção da capital. Em 17 de fevereiro de 1909, os jornais passaram a noticiar o interesse da empresa de Guinle em fornecer energia elétrica para a cidade "por preços excepcionais, nunca vistos, ao alcance das bolsas menos remediadas" ${ }^{40}$. Poucos dias depois, o jornal O Estado de São Paulo proclamava que o Prefeito Antonio Prado havia aceitado a proposta de Guinle, por meio de um despacho para a Câmara Municipal em 22 de fevereiro, acreditando que a legislação sobre os serviços urbanos da capital paulista era de livre-concorrência ${ }^{41}$.

Com a aprovação provisória de Antonio Prado, a CBEE deveria apresentar e aprovar as plantas das redes de energia elétrica no período de quatro meses, obedecendo à não instalação de suas redes nos lugares ocupados pela Light ${ }^{42}$. Com o monopólio ameaçado, a empresa canadense iniciou uma grande campanha nosjornais e na Câmara Municipal para barrar a determinação do prefeito de São Paulo.

Juridicamente, a Light buscou auxílio no formato dos serviços urbanos norte-americanos, apoiando-se na argumentação de doutrinas de advogados dos EUA, como Clarke Hare (American Constitutional Law) e John Dillon (Commentaries on the law on the municipal corporations). Francisco Castro Jr., um dos principais advogados da Light, escreveu, em 1909, um longo texto, considerando que a tendência da prestação de serviços municipais na Grã-Bretanha e nos EUA era de concessões em regime de monopólio, estrutura que deveria ser estendida para o Brasil (CASTRO JR., 1909: 15-7). No Brasil, apoiando a Light, a argumentação jurídica norte-americana seria reproduzida por importantes personagens, como Ruy Barbosa, que afirmava: "A livre competência entre tantas companhias e pessoas quantas quizessem estender fios para a conducção de eletricidade pelas ruas seria impraticável" (CASTRO JR., 1909: 18).

$\mathrm{Na}$ sociedade, a Light tentava conquistar o apoio da população por meio de campanhas publicitárias nos jornais. O principal jornal de apoio à Light era A Gazeta, fundado em 16 de maio de 1906, com a função de defender a empresa canadense, já que o capital de cinco contos de réis utilizado na fundação dojornal havia sido liberado por

4. A Gazeta, 17 de fevereiro de 1909.

${ }^{4}$ O Estado de São Paulo, 27 de fevereiro de 1909.

Idem, 13 de março de 1909. 
Alexander Mackensie, diretor da Light no Brasil (PONTES, 1995: 63). Assim, nos jornais, e especialmente em A Gazeta e em A Platéia, a argumentação recorrente em defesa da companhia canadensejustificava os altos custos para a instalação de um serviço público de energia elétrica e, por isto, a Light deveria funcionar em regime de concessão monopolista:

Bem diz o dictado: 'da discussão surge a luz', o que ao caso da Light $x$ Guinle se ajusta como luva em mão de moça bonita. Nunca chegamos a compreender, como um serviço público, indispensável, que depende da occupação do leito das ruas e do emprego de grandes capitaes, pudesse ser entregue aos azares da livre-concorrencia, como qualquer pequeno negócio de bugigangas ${ }^{43}$.

Outra alegação, presente na defesa do monopólio da Light no mercado da cidade de São Paulo, era a conceitualização da expressão "lugares ocupados". Na interpretação passada para a sociedade pelos empresários da Light, os lugares ocupados eram: whole of the streets, squares or other publics thoroughfares when then existed any canalization (LIGHT, 1909: 52). Para eles, a empresa canadense já tinha projetos para toda a cidade, que vinha implantando com o passar do tempo. Desta maneira, toda a cidade de São Paulo já estaria ocupada, não permitindo que outra empresa pudesse dividir o mercado com a Light. Com esta defesa, a empresa se contradizia com as lutas pelo mercado da capital paulista nos anos de sua instalação, quando, na Câmara Municipal, questionavam a idéia de lugares ocupados pelaViação Paulista e pela Companhia de Água e Luz, antigas concessionárias de serviços públicos de São Paulo. Apontando dubiedade e existência de filha na interpretação da expressão "lugares ocupados", descrita na lei $\mathrm{n}^{\circ} 407$, de 1899 , a Light defendia uma nova análise da concessão de seus serviços na Câmara Municipal, local em que a empresa mantinha fortes relações políticas (BARRO, 1995):

A íntima relação entre Light e políticos já era observada logo nos primeiros anos do estabelecimento da empresa no país. Compondo o establishment da Light estavam políticos como Carlos de Campos e Fer-

43 Platéia, 18 de julho de 1912. 
nando de Albuquerque, além do forte lobby existente nas instituições políticas e, especialmente, na Câmara Municipal de São Paulo. A defesa dos interesses lightianos na Câmara Municipal garantia determinados traçados dos trilhos dos bondes para alguns vereadores, como para os loteamentos de José Oswald Nogueira de Andrade ${ }^{44}$ em Santa Cecília e Campos Elíseos (BARRO, 1995).

Outro eficiente mecanismo utilizado pela Light para sustentar seus interesses na Câmara era o controle do "curral eleitoral", praticado com os funcionários da empresa. Nos anos de eleição, a Light, uma empresa que detinha um grande número de trabalhadores com possibilidade de votar, conseguia eleger certos vereadores que logo retribuíam com a incondicional defesa da empresa, como descrito nos jornais: "A Light arregimenta forças para dar batalha política dominante de São Paulo e não faz mystério que no próximo pleito, depois de ter alistado eleitores do seu enorme pessoal, reunirá maioria na Câmara Municipal dessa capital"4s.

As denúncias contra o controle político da Light sobre seus funcionários, momentos antes da eleição de 1907, foram intensas em jornais como O Commercio de São Paulo e O Estadode São Paulo. Na cidade de São Paulo, o colégio eleitoral ainda era extremamente restrito, com apenas cerca de 11 mil eleitores, e a Light, com seu poder econômico e mais de mil alistamentos, acabava por influir decisivamente na eleição para vereadores, prefeito, deputados e até mesmo governador (SEGATTO, 2002: 211-3). Governador eleito com apoio da Light, Albuquerque Lins era descrito pela empresa como "um homem bem conhecido da Companhia, e acredita-se que a atitude do novo governo será de manter as justas e agradáveis relações" (LIGHT, 1907: 8). A eleição de 1907 foi a que definiu os vereadores que participariam dos debates contra a CBEE. Antes da eleição, os jornais afirmavam:

Quem é admitido na Companhia tem que se alistar eleitor, por bem ou por mal, seja estrangeiro ou nacional. Mas, quando ela despede um operário ou quando ele se despede, vai-se o cidadão de mãos limpas. A Light

Pai de Oswald de Andrade, José Oswald foi vereador nas legislaturas de 1899-1902, de 1902-1905 e 1908-1911, participando ativamente na defesa dos interesses da Light na capital paulista.

45 O Estado de São Paulo, 19 dejaneiro de 1913. 
retém-lhe o título, como retém os títulos dos que estão enfermos, dos que morrem, dos que se ausentam (...). Amanhã, para vencer um pleito, para eleger os seus apaziguados, para ter prefeitos ou vereadores que lhe façam novas concessões ou que a desonerem de suas obrigações (...). Light convertida em núcleo eleitoral, tem no Congresso do Estado, nas próprias repartições municipais, quem a auxilie, que lhe dê apoio, quem a incite a prosseguir na sua intervenção imoral em nossa política (...). Em vésperas de eleições, os diretores da Light comprometem-se a dar a este ou àquele candidato determinado número de votos ${ }^{46}$.

Não é difícil de imaginar que a Light consolidou na Câmara Municipal de São Paulo um poder político determinante para enfrentar qualquer questão, fazendo com que O Estado de São Paulo proclamasse que "a Light era um Estado dentro do Município" “" Na avaliação da própria Light lia-se: "natural que estamos interessados nestas questões políticas e podemos muito bem congratularmo-nos, tal qual a população desta comunidade, acerca dos resultados destas eleições" (LIGHT, 1907). Para cooptar não só as instituições políticas, mas a população também, a empresa propôs uma série de medidas que auxiliavam a Câmara Municipal, além de beneficiar a população, incluindo: investimentos para obras de melhoramento da cidade, como a construção do Viaduto do Chá, a entrega de 40.000 contos anuais para uso e gozo da Câmara Municipal ${ }^{48}$ e a redução dos preços de luz de 800 para 500 réis e de 700 para 300 réis para força elétrica ${ }^{49}$.

Percebendo a movimentação tomada pela empresa canadense na Câmara Municipal e nos meios de comunicação para sustentar o monopólio nos serviços urbanos, os estudantes das faculdades de Direito e Engenharia de São Paulo foram às ruas, entre os dias 21 e 24 de abril de 1909, para questionar o parecer, em processo de aprovação na Câmara dos vereadores, que dava amplos poderes à Light. Ao mesmo tempo em que jornais como O Estado de São Paulo e A Notícia se posicionavam-a favor da CBEE, questionando o poder do "polvo canadense" e relatando pequenos acidentes causados pelos bondes da Light

4 O Com me rcio de São Paulo, 11 de julho de 1907.

* O Estado de São Paulo, 25 de junho de 1908 .

4 Brazil Ferro-Carril, no 30 , julho de 1912, p. 145.

4. A Platéia, 11 de março de 1909. 
para mobilizar a população (CARONE \& PERAZZO, 1990: 40-4), os estudantes universitários defendiam o interesse de Antonio Prado quanto à livre-concorrência e partiam para a agressão contra o patrimônio da Light. A Notícia comparava em seus artigos os serviços de eletricidade no Rio de Janeiro com os de São Paulo, argumentando que Antonio Prado era um grande prefeito ao barrar o monopólio da Light, diferente do Rio de Janeiro, em que não existiam forças políticas suficientes para livrar a capital brasileira do monopólio canadense ${ }^{50}$. Combatendo as estratégias políticas da "Light, ojornal acentua a posição límpida do prefeito, que afastava a tentativa de suborno proposta pelos diretores da Light", posicionando-se "contrário aos preços extorsivos cobrados pela Light - cinco vezes superior ao valore real" ${ }^{51}$.

No centro da cidade, bondes eram apedrejados e assaltados e gritos de ordem eram pronunciados contra a empresa canadense e a Câmara Municipal, como "Abaixo a Light! Abaixo o monopólio!", que somente foram abafados com a repressão da Guarda Cívica. Com a população relativamente controlada e com os conchavos políticos estabelecidos, em 29 de abril de 1909 era votada a lei $\mathrm{n}^{\circ}$ 1.210, interpretando as regras para concessionários dos serviços públicos. A Light, com facilidade, acabava vitoriosa no pleito da Câmara Municipal, com 12 votos contra apenas 3 entre os 16 vereadores ${ }^{52}$, e a empresa assim noticiou a vitória em seu relatório:

We (Light) appealed to the Municipal Council, a body composed of 16 members, who, after strong debates in different session, approved a new law $n^{\circ} 1210$, on the $29^{\text {in }}$ April 1909, interpretating the aforementioned law n. 407 regard lhe meaning of the word places. According to this new law, therefore, this company has now the exclusive right until 1919 to place canalizations in streets already occupied by it ( LIGH T, 1909: 48-50).

Diante da não aprovação da Câmara de Vereadores de São Paulo, Antonio Prado revogava sua decisão de meses anteriores:

" Como vimos, no Rio de Janeiro os conflitos foram também intensos, diferente do que alega ojornal.

A Notícia, 2 de março de 1909.

Câmara Municipal, 29 de abril de 1909. 
[...] sobre a installação e distribuição de luz e força elétrica dos logares occupados, - o dr. Prefeito municipal, vendo cessada essa atribuição que a lei de 1899 lhe dava, não approvou as plantas apresentadas pela firma Guinle e Comp.,para a distribuição de energia electrica nos 4 sectores da cidade, e declarou sem effeito o seu despacho de 22 de fevereiro de 1909 , pelo qual autorizava aquella firma a installar o seu serviço de distribuição de força e luz electrica ${ }^{53}$.

O encaminhamento dado pela Câmara dos vereadores de São Paulo ampliava consideravelmente o poder da Light na capital paulista. Nos anos seguintes, os debates se reduziram, até o ano de 1912, quando a empresa buscou requerer da Câmara a unificação de seus contratos de transporte e iluminação, ampliando o período de monopólio. Antes mesmo que os questionamentos por parte da sociedade e da CBEE voltassem à tona, a Light já garantia alianças políticas, como com o novo prefeito de São Paulo, Raymundo Duprat, escrevendo no relatcirio da empresa o seguinte: we antecipate a relationship with the new administration of the upmost cordially (LIGHT, 1910:1-8) ${ }^{54}$. A prorrogação da concessão para mais cinqüenta anos era grande desejo da empresa canadense para construir, então, o Império dos serviços públicos no Brasil, fundado em 1913, denominado Brazilian Traction Light and Power Co. Ltd., unindo as concessões de São Paulo, Rio de Janeiro, Sorocaba e outras importantes cidades.

Novamente, os interesses da família Guinle não haviam alcançado o desejado na capital paulista. Por mais que outra campanha nacionalista tivesse sido elaborada em 1912, arregimentando força na Câmara e na sociedade, não foi suficiente para quebrar o forte lobby da Light, que manteve privilégio nos fornecimentos dos serviços de eletricidade na cidade de São Paulo até 1979.

\section{Conclusão}

Os primeiros anos do século XX foram marcados por profundas disputas entre empresas nacionais e estrangeiras quanto ao forneci-

\footnotetext{
${ }^{53}$ Diário Popular, 1 de maio de 1909.

${ }^{s}$ Raymundo Duprat era vereador de São Paulo em 1909 e havia participado das discussões sobre a concessão da Light, sendo um cios principais defensores da empresa.
} 
mento de serviços públicos para as cidades brasileiras que se desenvolviam. Entre as que mais se destacavam estavam o Rio de Janeiro, o centro político da República e primeiro centro industrial do país, e São Paulo, que passava por grandes transformações econômicas vinculadas à expansão do comércio agrário-exportador. Além da importância econômica, as duas cidades se destacavam pelo crescimento urbano que as colocavam entre as principais cidades da América Latina em tamanho populacional. Diante da proeminência destes dois centros, a empresa canadense Light e a nacional CBEE concorreram acuradamente para deter as concessões dos serviços de energia elétrica nesses municípios.

Os conflitos entre as empresas perpassaram diversas instâncias públicas, os meios de comunicação e até mesmo o posicionamento da sociedade em tal embate. Por mais que os empresários cariocas da CBEE tivessem ampla circulação entre respeitáveis políticos e aceitação entre jornais é grupos sociais nacionalistas, tanto em São Paulo como no Rio de Janeiro, a empresa perdeu a concorrência e a possibilidade de fornecer energia elétrica para a canadense Light. Neste sentido, acreditamos que uma variável importante para ser analisada, a fim de compreender a organização política dos serviços públicos no período da Primeira República, estájustamente na composição de poder existente nas Câmaras Municipais. Por mais que os empresários da Light tivessem essenciais ligações com diferentes hierarquias políticas da época, até mesmo com presidentes de estado e do governo federal, foram as sólidas conexões com o poder municipal que possibilitaram o desenvolvimento da empresa no mercado nacional, já que, na falta de uma legislação federal, as decisões sobre os serviços públicos ficavam à revelia dos interesses dos vereadores.

\section{Referências bibliográficas}

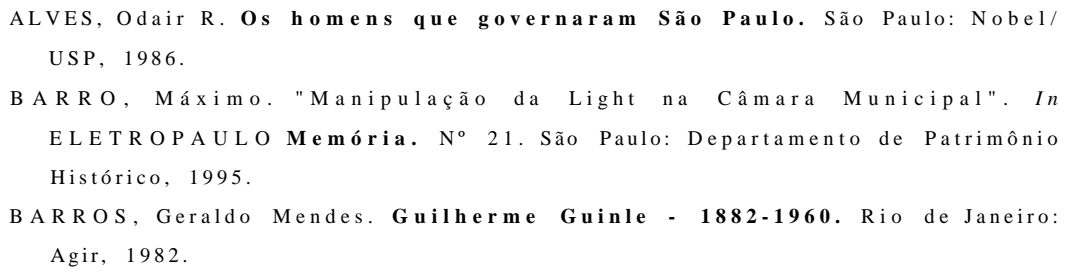


B EnCHimol, Jaime Larry. Pereira Passos: um Haussmann Tropical. Rio de Janeiro: Secretaria Municipal de Cultura, Turismo e Esportes, Departamento Geral de documentação e Informação Cultural, 1992.

C A R O E, Edgar. O Centro Industrial Rio de Janeiro e sua Importante Participação na Economia Nacional (1827-1977). Rio de Janeiro: Ed. Cátedra, 1978 .

CARONE, Edgar \& PERAZZO, Priscila."Em São Paulo, lutas contra o monopólio. A mobilização social no conflito Guinle x Light." In ELETROPAULO. Me mó ria, III (7). São Paulo: Eletropaulo, 1990.

C A S T Ro JR., Francisco de. O privilégio da Light and Power. Rio de Janeiro: Papelaria Americana, 1909 .

COR REA A, M a ria Letícia."As Idéias Econômicas na Primeira República: Serzedelo Corrêa,Vieira Souto e Nilo Peçanha". Niterói: UFF, 1996. (Mestrado em História). GRAMSCI, Antônio. A Concepção Dialética da História. Tradução de Carlos Nelson Coutinho. 7* ed. Rio de Janeiro: Ed. Civilização Brasileira, 1966.

- Maquiavel, a Política e ostado Moderno. Rio de Janeiro: Civilização Brasileira, 1978 .

HONORATO, Cezar. "No Rio, conflitos entre capitalistas." In ELETROPULO. Memória, III (7). São Paulo: Eletropaulo, 1990.

O.polvo e o porto. A Cia. Docas de Santos (1888-1914). São PauloSantos: Hucitec/Prefeitura Municipal de Santos, 1996.

K A W A M R A, Lili Katsuco. Engenheiro: trabalho e ideologia. 2a ed. São Paulo: Ática, 1981 .

L A MAR Ão, Sérgio T. Niemeyer. "A energia elétrica e o parque industrial carioca (1880-1920)". Niterói: ICHF/UFF, 1997 (Tese de Doutorado).

LEOPOLDI, Maria Antonieta, "Crescimento industrial, políticas governamentais e organização da burguesia: o Rio de Janeiro de 1844 a 1914 ". Revista do Rio de Janeiro, Niterói.Vol. I, n³ 3, 1986.

LigTh ." The São Paulo Tramway, Light and Power Company Ltd.". Animal Report. São Paulo: datilografado, $1902-1920$.

L O B O, Eulália. História do Rio de Janeiro. Do capital industrial e financeiro. Rio de Janeiro: IB MEC, 1978.

MA Tos, Maria Izilda Santos. Trama \& Poder: trajetória e polêmica em torno das indústrias dejuta. Rio de Janeiro: Sete Letras, 1996.

McDow A L L, Duncan. The Light. Brazilian traction, Light and Power Company Limited - 1899-1945. Toronto: University of Toronto Press, 1988.

MEN D O ÇA, Sônia Regina de. O Ruralismo Brasileiro (1888-1931). São Paulo: Hucitec, 1997.

OLIVEIRA, Francisco de. "A emergência do modo de produção de mercadorias: uma interpretação teórica da economia na RepúblicaVelha no Brasil". In FAUSTO, Boris (org.) História Geral da Civilização Brasileira (III).V.1. São Paulo: Ditei, 1975 .

80 I Cláudia Regina Salgado de Oliveira Hansen - Alexandre Macchione Saes 
PONTES,José Alfredo."A Light e a imprensa." In ELETROPAULO. Memória. N"

22. São Paulo: Departamento de Patrimônio Histórico, 1995.

SCHOPPA. Renê Fernandes. 150 Anos do Trem no Brasil: 30 de Abril de

1854-2004. S/ed., 2004 .

SEGATTO,José Antonio. "Relações e conflitos de trabalho na Light de São Paulo".

In SZMRECSÁN Y I, Tamás e MARANH ÃO, Ricardo. História de e mpresas

e desenvolvimento econômico. São Paulo: Hucitec/Edusp/Imprensa Oficial, 2002 .

SILVA, Heloísa Barbosa da."Batalhas pelo monopólio". In ELET R OPAULO. Histó -

ria e Energia. A chegada da Light. São Paulo: Departamento de Patrimônio Histórico, 1986.

SoUZA, Edgar de. A história da Light. Os primeiros 50 anos. São Paulo: Eletropaulo, 1982 .

TEIXEIRA, Palmira Petratti. A fábrica do sonho.Trajetória do industrial Jorge Street. São Paulo: Paz e Terra, 1990.

T URAZZI, Maria Inês. A euforia do progresso e a imposição da ordem: a Engenharia, a indústria e organização do trabalho na virada do século XIX e início do XX. Rio de Janeiro: Coppe, São Paulo: Marco Zero, 1989. 